\title{
Characterization of serum protein electrophoresis patterns and C-reactive protein in canine tick-borne diseases
}

\author{
Sariya Asawakarn ${ }^{1,2}$ id and Piyanan Taweethavonsawat ${ }^{2,3}$ (i) \\ 1. Biochemistry Unit, Department of Veterinary Physiology, Faculty of Veterinary Science, Chulalongkorn University, \\ Bangkok 10330, Thailand; 2. Biomarkers in Animals Parasitology Research Group, Chulalongkorn University, Bangkok \\ 10330, Thailand; 3. Parasitology Unit, Department of Veterinary Pathology, Faculty of Veterinary Science, Chulalongkorn \\ University, Bangkok, 10330, Thailand. \\ Corresponding author: Piyanan Taweethavonsawat, e-mail: piyanan.t@chula.ac.th \\ Co-author: SA: sariya.a@chula.ac.th \\ Received: 01-04-2021, Accepted: 19-07-2021, Published online: 21-08-2021 \\ doi: www.doi.org/10.14202/vetworld.2021.2150-2154 How to cite this article: Asawakarn S, Taweethavonsawat $P$ \\ (2021) Characterization of serum protein electrophoresis patterns and C-reactive protein in canine tick-borne diseases, \\ Veterinary World, 14(8): 2150-2154.
}

\begin{abstract}
Background and Aim: Canine tick-borne diseases are important diseases with a worldwide distribution. In Thailand, the most important canine tick-borne diseases are ehrlichiosis, babesiosis, and hepatozoonosis. This study aimed to determine the serum protein electrophoresis patterns (SPEPs) and C-reactive protein (CRP) levels associated with Ehrlichia canis, Babesia canis, or Hepatozoon canis single infections.

Materials and Methods: A total of 650 canine blood samples were collected from animal hospitals and clinics in Bangkok and its vicinity to examine health status and blood parasite infection. Suspected blood parasite infections were examined by buffy coat thin blood smear and confirmed by polymerase chain reaction. Normal dog and positive E. canis, B. canis, and $H$. canis single infections and serum protein profiles were determined by agarose gel electrophoresis. CRP concentration was measured by fluorescent immunoassay.

Results: In dogs infected with E. canis, B. canis, and H. canis single infections, albumin levels and A/G ratios significantly decreased, whereas $\beta 2$-globulin levels increased $(\mathrm{p}<0.05)$. The $\gamma$-globulin level significantly increased in $E$. canis and $H$. canis infections $(\mathrm{p}<0.05)$. A monoclonal gammopathy pattern was observed in $E$. canis and B. canis single infections, whereas $\beta-\gamma$ bridging patterns and increased $\beta$ - and $\gamma$-globulin fractions were found in $H$. canis single infections. The CRP level increased in dogs with blood parasite single infections and may be related to the pathogenesis of the infection.
\end{abstract}

Conclusion: SPEPs and CRP levels can be used to monitor health status and blood parasite problems in infected dogs.

Keywords: blood parasites, C-reactive protein, dog, electrophoresis, serum protein.

\section{Introduction}

Canine tick-borne diseases are transmitted by hard tick species, such as the brown dog tick (Rhipicephalus sanguineus), which is common in Thailand [1] and is distributed worldwide [2]. Ticks not only feed on blood cells but also transmit different types of pathogens, such as protozoa, viruses, rickettsia, and bacteria [3], causing both morbidity and mortality. Ehrlichia canis, Babesia canis vogeli, and Hepatozoon canis are commonly found in Thailand [4,5]. Ehrlichiosis and babesiosis can develop when a dog is bitten by an infected tick, but hepatozoonosis is caused by its ingestion. B. canis subspecies vogeli is the main species causing canine babesiosis in Thailand [5]. B. canis is the large form of Babesia spp. Babesia organisms enter and multiply in the host erythrocytes. Clinical manifestations

Copyright: Asawakarn and Taweethavonsawat. Open Access. This article is distributed under the terms of the Creative Commons Attribution 4.0 International License (http://creativecommons. org/licenses/by/4.0/), which permits unrestricted use, distribution, and reproduction in any medium, provided you give appropriate credit to the original author(s) and the source, provide a link to the Creative Commons license, and indicate if changes were made. The Creative Commons Public Domain Dedication waiver (http:// creativecommons.org/publicdomain/zero/1.0/) applies to the data made available in this article, unless otherwise stated. are anorexia, lethargy, pale mucous membranes, fever, jaundice, chronic nephropathy, and glomerulonephritis [6]. The severity of infection depends on the subspecies of canine babesiosis. B. canis causes a subclinical to a mild degree of infection [6,7]. $E$. canis is a Gram-negative intracellular rickettsia that can infect monocytes and lymphocytes in dogs [8]. Canine ehrlichiosis can be classified into three stages according to clinical signs: Acute, subclinical, and chronic. In the acute stage, clinical signs appear at 1-3 weeks after infection and include fever, weakness, lethargy, depression, lack of appetite, and limb edema. In the subclinical stage, the organism may be present for months to years without clinical symptoms. In the chronic stage, the infected dog has abnormal bleeding due to thrombocytopenia, severe weight loss, fever, difficulty in breathing due to lung inflammation, joint pain, seizures in some cases, lack of coordination, anemia, and kidney failure [9]. H. canis is an apicomplexan parasite that belongs to the family Hepatozoidae. The clinical signs of $H$. canis infection can vary from subclinical to severe and life-threatening. The most frequently observed clinical signs are anemia, extreme lethargy, intermittent fever, and emaciation [7]. 
Serum protein electrophoresis patterns (SPEPs) show fractions of two major types of protein: Albumin and globulin. Albumin is the single most abundant protein in the serum and is synthesized by the liver. Globulins are also synthesized by the liver, except for immunoglobulins. In dogs, globulin fractions can be separated into five fractions: $\alpha 1, \alpha 2, \beta 1, \beta 2$, and $\gamma$. The measurement of serum protein may help detect and monitor various diseases and pathological processes. SPEPs can be used as a diagnostic tool in a wide spectrum of diseases, including infectious and inflammatory diseases, renal, hepatic, and gastrointestinal disorders, immunodeficiency status, and paraproteinemia, caused by plasma cell neoplasia [10]. The acute-phase response is considered part of the innate host defense system, and the systemic effects include leukocytosis, fever, and increased blood cortisol. C-reactive protein (CRP) is one of the acute-phase proteins and is synthesized by hepatocytes, smooth muscle cells, macrophages, endothelial cells, lymphocytes, and adipocytes. It is a major acute-phase protein in dogs and is part of the $\gamma$-globulin fraction. Its concentration increases dramatically in response to inflammation, infection from pathogens (including bacteria and parasites), and injury and has been used as a predictive marker for disease risk and to monitor the response to treatment [11].

This study aimed to investigate the SPEPs and CRP concentrations associated with single infections of E. canis, B. canis, and H. canis.

\section{Materials and Methods}

\section{Ethical approval}

The research protocol was approved by the Institutional Review Board of Chulalongkorn University Animal Committee (approval no. 1931052). All methods were performed in accordance with relevant guidelines and regulations.

\section{Study period and location}

Blood samples were collected from Bangkok and its vicinity area during January-December 2020.

\section{Sample collection}

A total of 650 canine (Canis familiaris) blood samples were collected and examined for health status and blood parasite infection. Some cases showed clinical signs of blood parasite infection, including anorexia, lethargy, pale mucous membranes, and fever. Only a few cases exhibited jaundice. Samples were collected in EDTA tubes and serum collection tubes and suspected blood parasite infections were examined by buffy coat thin blood smear and confirmed by polymerase chain reaction according to Rucksaken et al. [8]. The numbers of dogs with $B$. canis, E. canis, or H. canis single infections were 13, 20 , and 14 , respectively. The criteria for normality were healthy dogs with no clinical signs of blood parasite infection and no history of ectoparasite infestation. Blood chemistry profiles of normal dogs were in the normal range [12]. All serum samples were kept at $-20^{\circ} \mathrm{C}$ until analysis.

Serum protein profile determination and
electrophoresis

Serum from normal $(\mathrm{n}=9), B$. canis $(\mathrm{n}=13), E$. canis $(\mathrm{n}=20)$, and $H$. canis $(\mathrm{n}=14)$ single infections was analyzed for total serum protein and SPEPs. Total serum protein was measured by the Biuret colorimetric test (Human ${ }^{\circledR}$, Wiesbaden, Germany). The serum protein samples were separated by agarose gel electrophoresis $\left(\right.$ SPIFE $^{\circledR}$ split beta SPE kit; Helena Laboratories, TX, USA). Fifteen microliters $(1.3 \mathrm{mg})$ of the serum protein sample were placed in each well, and electrophoresis was performed at $400 \mathrm{~V}$ for $6 \mathrm{~min}$. The gel was pre-dried at $53^{\circ} \mathrm{C}$ for $12 \mathrm{~min}$, stained with acid blue staining solution, and destained in citric acid destaining solution. All steps were carried out in an automated machine (Spife ${ }^{\circledR}$ 3000; Helena Laboratories). The density of each serum protein band in the electrophoresis pattern was measured and analyzed using QuickScan Touch (Helena Laboratories).

\section{Measurements of CRP concentration}

CRP concentrations of blood parasite-positive serum samples were measured by fluorescent immunoassay (Vcheck Canine CRP 2.0 Test kit; Bionote, South Korea). About $5 \mu \mathrm{L}$ of each sample was diluted in $4 \mathrm{~mL}$ diluent buffer from the test kit. About $100 \mu \mathrm{L}$ of the diluted sample was mixed and added to the test device. The CRP concentration was displayed on the screen after $5 \mathrm{~min}$. A CRP concentration above $30 \mathrm{mg} / \mathrm{L}$ was considered abnormal.

\section{Statistical analysis}

SPEP data for blood parasite single infections were tested using analysis of variance. Tukey's test was used for pairwise comparisons between single infections and normal dogs. Significance was set at $p<0.05$. The normal distribution of SPEP data was tested using GraphPad Software, (GraphPad, San Diego, CA, USA).

\section{Results}

SPEPs were determined by agarose gel electrophoresis (Figure-1). Tables-1 and 2 show the total protein, albumin, and globulin fractions and $\mathrm{A} / \mathrm{G}$ ratios in single blood parasite infections. Comparisons were made among single infections of $B$. canis, E. canis, or $H$. canis in normal dogs and between groups. There were no significant differences among the three groups of blood parasite infections. In this study, the monoclonal gammopathy was 39\% (5 of 13 ) of B. canis and $35 \%$ (7 of 20) of E. canis single infections. In dogs with $H$. canis single infection, the serum protein pattern showed $\beta-\gamma$ bridging and an increase in $\beta$ - and $\gamma$-globulin peaks in $43 \%$ (6 of 14) of the cases.

CRP concentrations were detected by fluorescent immunoassay. CRP concentrations in dogs infected with $B$. canis $(\mathrm{n}=6)$ were between 52.0 and $200.0 \mathrm{mg} / \mathrm{L}$, with a mean of $127.62 \mathrm{mg} / \mathrm{L}$. In dogs infected with 


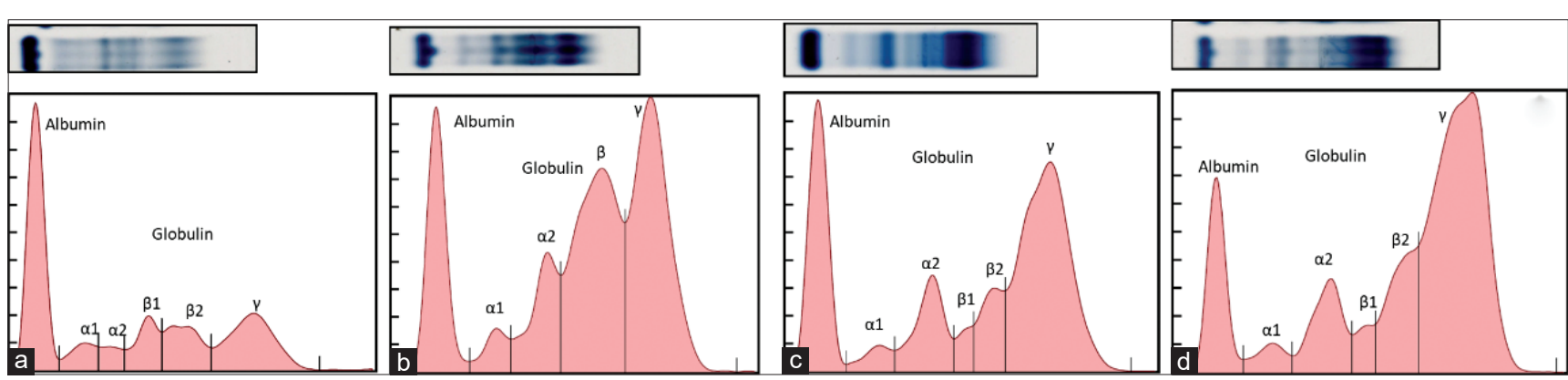

Figure-1: Representations of the serum electrophoresis patterns of normal dogs (A) and dogs with single infection with Ehrlichia canis (B), Babesia canis (C), and Hepatozoon canis (D).

Table-1: The results of relative concentration of serum protein fraction (\%) and albumin/globulin (A/G) ratio in normal dogs and dogs infected with Babesia canis, Ehrlichia canis, or Hepatozoon canis single infections (mean \pm SD).

\begin{tabular}{|c|c|c|c|c|c|}
\hline Variables & $\begin{array}{c}\text { Normal } \\
(n=9)\end{array}$ & $\begin{array}{c}\text { Babesia canis } \\
\quad(n=13)\end{array}$ & $\begin{array}{c}\text { Ehrlichia canis } \\
(n=20)\end{array}$ & $\begin{array}{c}\text { Hepatozoon canis } \\
(\mathrm{n}=14)\end{array}$ & p-value \\
\hline Albumin & $42.43 \pm 6.29$ & $32.38 \pm 9.29 *$ & $27.18 \pm 7.84 *$ & $23.15 \pm 11.64 *$ & $<0.05$ \\
\hline a1-globulin & $6.02 \pm 1.86$ & $5.85 \pm 2.96$ & $5.19 \pm 1.80$ & $3.80 \pm 1.72 *$ & $<0.05$ \\
\hline a2-globulin & $6.40 \pm 3.95$ & $8.35 \pm 5.62$ & $10.87 \pm 5.78 *$ & $6.74 \pm 5.42$ & $<0.05$ \\
\hline$\beta 1$-globulin & $10.40 \pm 4.47$ & $10.92 \pm 5.30$ & $10.20 \pm 5.72$ & $10.54 \pm 6.81$ & n.s. \\
\hline$\beta 2$-globulin & $13.90 \pm 4.30$ & $18.89 \pm 14.10 *$ & $20.81 \pm 8.23 *$ & $20.11 \pm 9.07 *$ & $<0.05$ \\
\hline Y-globulin & $25.32 \pm 8.71$ & $23.57 \pm 13.25$ & $25.93 \pm 9.87$ & $33.89 \pm 10.43 *$ & $<0.05$ \\
\hline $\mathrm{A} / \mathrm{G}$ ratio & $0.74 \pm 0.19$ & $0.51 \pm 0.20 *$ & $0.39 \pm 0.17^{*}$ & $0.38 \pm 0.23 *$ & $<0.05$ \\
\hline
\end{tabular}

p-value-significance of the analysis of variance; n.s.=Not significant. *Significant difference between normal and Babesia canis, Ehrlichia canis, or Hepatozoon canis at $\mathrm{p}<0.05$

Table-2: The results of total protein and absolute values of protein fraction $(\mathrm{g} / \mathrm{L})$ in normal dogs and dogs infected with Babesia canis, Ehrlichia canis, or Hepatozoon canis single infections (mean \pm SD).

\begin{tabular}{|c|c|c|c|c|c|}
\hline $\begin{array}{l}\text { Variables } \\
(\mathrm{g} / \mathrm{L})\end{array}$ & $\begin{array}{c}\text { Normal } \\
(n=9)\end{array}$ & $\begin{array}{c}\text { Babesia canis } \\
(n=13)\end{array}$ & $\begin{array}{l}\text { Ehrlichia canis } \\
\quad(n=20)\end{array}$ & $\begin{array}{c}\text { Hepatozoon canis } \\
(\mathrm{n}=14)\end{array}$ & p-value \\
\hline Total protein & $88.47 \pm 7.26$ & $68.25 \pm 16.46$ & $86.19 \pm 22.26 *$ & $96.67 \pm 30.65^{*}$ & $<0.05$ \\
\hline Albumin & $24.22 \pm 9.72$ & $25.08 \pm 8.34$ & $22.85 \pm 6.63$ & $22.29 \pm 4.70$ & n.s. \\
\hline a1-globulin & $3.78 \pm 2.44$ & $4.08 \pm 1.80$ & $4.40 \pm 2.04$ & $3.57 \pm 1.83$ & n.s. \\
\hline a2-globulin & $4.00 \pm 3.84$ & $6.31 \pm 4.71$ & $9.40 \pm 5.88^{*}$ & $7.00 \pm 6.85$ & $<0.05$ \\
\hline$\beta 1$-globulin & $6.33 \pm 4.66$ & $8.00 \pm 4.14$ & $8.65 \pm 4.99$ & $10.79 \pm 8.27$ & n.s. \\
\hline$\beta 2$-globulin & $12.00 \pm 3.61$ & $13.43 \pm 12.14^{*}$ & $17.90 \pm 8.44^{*}$ & $21.64 \pm 13.60 *$ & $<0.05$ \\
\hline$Y$-globulin & $13.67 \pm 5.32$ & $18.62 \pm 13.55$ & $23.00 \pm 12.17 *$ & $34.86 \pm 17.58 *$ & $<0.05$ \\
\hline
\end{tabular}

p-value - significance of the analysis of variance; n.s. $=$ Not significant. *Significant difference between normal and Babesia canis, Ehrlichia canis, or Hepatozoon canis at $\mathrm{p}<0.05$

E. canis (n=6), CRP concentrations were between 50.2 and $166.7 \mathrm{mg} / \mathrm{L}$, with a mean of $105.35 \mathrm{mg} / \mathrm{L}$. In dogs infected with $H$. canis $(\mathrm{n}=6)$, CRP concentrations were between 10.0 and $51.2 \mathrm{mg} / \mathrm{L}$, with a mean of $45.6 \mathrm{mg} / \mathrm{L}$. Dogs had increased CRP concentration, so their health status had to be observed during the treatment method.

\section{Discussion}

Serum protein profile is one of the standard tests used to monitor health and disease status, such as infections and acute and chronic inflammatory responses. In this study, the average relative concentration of serum protein fraction albumin levels and A/G ratios significantly decreased, whereas the absolute total protein of $H$. canis significantly increased. Decreased albumin concentrations are usually caused by acute inflammation, liver damage, starvation or cachexia, digestive disorders, or kidney diseases [13]. However, the pathogenesis of B. canis, H. canis, and $E$. canis infections is usually caused by acute inflammation and/or liver damage $[9,14]$. Decreased A/G ratios result from a reduction in albumin concentrations and an increase in globulin concentrations. In the previous report, ehrlichiosis (in subclinical and chronic diseases) was associated with significant hypoalbuminemia, hyperglobulinemia, and hypergammaglobulinemia [15]. The serum protein profile of B. canis-infected dogs showed decreased albumin concentrations and $\mathrm{A} / \mathrm{G}$ ratios but increased $\alpha$ - and $\beta$-globulin concentrations. The abnormalities in $\beta$-globulin concentrations might be due to hypertransferrinemia $[16,17]$. The total protein of $H$. canis increased, probably due to hyperglobulinemia caused by the stimulation of the humoral response of the organism to severe chronic inflammation $[18,19]$.

For the globulin fraction, the relative concentrations and absolute values of $\beta 2$-globulin protein levels significantly increased in $B$. canis, $H$. canis, and $E$. 
canis infections. An increased $\beta 2$-globulin level may result from increased $\mathrm{C} 3 \mathrm{a}$ (complement) protein concentrations. Complements are involved in the regulation of inflammatory processes, and this complement protein plays a role in the development of intravascular hemolysis, especially in babesiosis $[16,17]$. The $\gamma$-globulin fractions increased in all three groups, with significantly increased absolute protein values in $E$. canis and $H$. canis infections. The $\gamma$-globulin fraction consists of various classes of immunoglobulins, and an increase in the fraction could lead to monoclonal gammopathy (narrow peak) or polyclonal gammopathy (broad peak). Monoclonal gammopathies result from a single line of B lymphocytes or plasma cells, whereas polyclonal gammopathies are usually an indication of chronic inflammation and chronic liver damage [13]. In this study, monoclonal gammopathy was found in $35 \%$ of E. canis and $39 \%$ of B. canis single infections. In a previous study, polyclonal and benign monoclonal gammopathies were observed in $E$. canis-infected dogs [20]. In dogs with $H$. canis single infection, the serum protein pattern showed $\beta$ - $\gamma$ bridging and an increase in the $\beta$ - and $\gamma$-globulin peaks in $43 \%$ of the cases. The $\beta-\gamma$ bridging pattern is usually found in liver damage [21]. The $\gamma$-globulin concentrations of $H$. canis single infection differed significantly from other blood parasite infections because hepatozoonosis has a longer life cycle than others and produces a chronic immune response [14].

CRP is a major acute-phase protein in dogs, mostly synthesized in the liver after tissue damage caused by infection, inflammation, or trauma. The acute-phase response is an innate host defense mechanism during tissue injury or immunological disorders and in the early stage of blood parasite infections. It is responsible for the accumulation and activation of granulocytes and mononuclear cells, releasing cytokines, interleukin (IL)-1, IL-16, and tumor necrosis factor- $\alpha$ [22]. In this study, the average CRP concentrations in dogs with E. canis, B. canis, and H. canis single infections were higher than the reference range $(>30 \mathrm{mg} / \mathrm{L})$. The average CRP concentration in $B$. canis single infection was higher than $E$. canis and $H$. canis single infections. In canine hepatozoonosis, most dogs were within normal levels, and a few increased. In a previous study, the CRP concentration in dogs infected with $E$. canis increased during the acute stage of infection; this increase could eliminate $E$. canis in macrophages of infected dogs. The CRP level might help assess the severity of inflammatory damage in E. canis-infected dogs, and veterinarians may use this information to choose inflammatory therapy [23]. The typical hematological abnormality of blood parasite infections, including ehrlichiosis, babesiosis, and hepatozoonosis, is anemia. Ehrlichiosis and babesiosis might be caused by canine immune-mediated anemia (IMHA) [24,25]. Serum CRP concentrations in canine autoimmune hemolytic anemia and primary IMHA are increased [26,27].

\section{Conclusion}

SPEPs in a blood parasite single infection mostly showed decreased albumin levels and $\mathrm{A} / \mathrm{G}$ ratios and increased $\beta 2-$ and $\gamma$-globulin levels. CRP concentrations extremely increased in dogs with all blood parasite infections. SPEPs and CRP levels can help veterinarians monitor health status and blood parasite problems in sick dogs during the treatment process.

\section{Authors' Contributions}

SA and PT: Designed the study, corrected data, data analysis and interpretation, and drafted the manuscript. The authors have read and approved the final manuscript.

\section{Acknowledgments}

The authors would like to thank Assist. Prof. Chatree Khatiworavage for the statistical analysis. This study was funded by the Special Task Force for Activating Research, Chulalongkorn University (STF 6401531001-1).

\section{Competing Interests}

The authors declare that they have no competing interests.

\section{Publisher's Note}

Veterinary World remains neutral with regard to jurisdictional claims in published and institutional affiliation.

\section{References}

1. Eamudomkarn, C. (2017) Tick-borne pathogens and their zoonotic potential for human infection in Thailand. Vet. Integr. Sci., 15(3): 127-136.

2. Otranto, D., Dantas-Torres, F., Giannelli, A., Latrofa, M.S., Cascio, A., Cazzin. S., Ravagnan, S., Montarsi, F., Zanzani, S.A. and Manfredi, M.T. (2014) Ticks infesting humans in Italy and associated pathogens. Parasit. Vectors, 7(1): 1-9.

3. de la Fuente, J., Estrada-Pena, A., Venzal, J.M., Kocan, K.M. and Sonenshine, D.E. (2008) Overview: Ticks as vectors of pathogens that cause disease in humans and animals. Front. Biosci., 13(13): 6938-6946.

4. Jittapalapong, S., Rungphisutthipongse, O., Maruyama, S., Schaefer, J.J. and Stich, R.W. (2006) Detection of Hepatozoon canis in stray dogs and cats in Bangkok, Thailand. Ann. N. Y. Acad. Sci., 1081(1): 479-488.

5. Rawangchue, T. and Sungpradit, S. (2020) Clinicopathological and molecular profiles of Babesia vogeli infection and Ehrlichia canis coinfection. Vet. World, 13(7): 1294.

6. Solano-Gallego, L., Sainz, Á., Roura, X., Estrada-Peña, A. and Miró, G., (2016) A review of canine babesiosis: The European perspective. Parasites, 9(1): 1-18.

7. Baneth, G. (2011) Perspectives on canine and feline hepatozoonosis. Vet. Parasitol., 181(1): 3-11.

8. Rucksaken, R., Maneeruttanarungroj, C., Maswanna, T., Sussadee, M. and Kanbutra, P. (2019) Comparison of conventional polymerase chain reaction and routine blood smear for the detection of Babesia canis, Hepatozoon canis, Ehrlichia canis, and Anaplasma platys in Buriram Province, Thailand. Vet. World, 12(5): 700.

9. Ogbu, K.I., Olaolu, O.S., Ochai, S.O. and Tion, M.T. (2018) A review of some tick-borne pathogens of dogs. Int. J. Vet. 
Sci. Med., 3(5): 140-153.

10. Tothova, C., Nagy, O. and Kovac, G. (2016) Serum proteins and their diagnostic utility in veterinary medicine: A review. Vet. Med., 61(9): 475-496.

11. Sproston, N.R. and Ashworth, J.J. (2018) Role of C-reactive protein at sites of inflammation and infection. Front. Immunol., 13 (9): 754.

12. Kaneko, J.J. (1997) Serum proteins and the dysproteinemias. In: Clinical Biochemistry of Domestic Animals. Elsevier, Amsterdam, Netherlands. p117-138.

13. Jania, B. and Andraszek, K. (2016) Application of native agarose gel electrophoresis of serum proteins in veterinary diagnostics. J. Vet. Res., 60(4): 501-508.

14. Greene, C.E. (2006). Infectious Diseases of the Dog and Cat. $3^{\text {rd }}$ ed. WB Saunders, Elsevier Science, United States.

15. Harrus, S., Waner, T., Avidar, Y., Bogin, E., Peh, H. and Bark, H. (1996) Serum protein alterations in canine ehrlichiosis. Vet. Parasitol., 66(3-4): 241-249.

16. Zygner, W., Gojska-Zygner, O. and Wędrychowicz, H. (2011) Abnormalities in serum proteins in the course of babesiosis in dogs. Bull. Vet. Inst. Pulawy, 55(1): 59-65.

17. Tóthová, C., Karasová, M., Blaňarová, L., Fialkovičová, M. and Nagy, O. (2020) Differences in serum protein electrophoretic pattern in dogs naturally infected with Babesia gibsoni and Babesia canis. Sci. Rep., 10(1): 1-9.

18. Vavricka, S.R., Burri, E., Beglinger, C., Degen, L. and Manz, M. (2009) Serum protein electrophoresis: An underused but very useful test. Digestion, 79(4): 203-210.

19. Paiz, L.M., Silva, R.C., Satake, F. and Fraga, T.L. (2016) Hematological disorders detected in dogs infected by Hepatozoon canis in a municipality in Mato Grosso do Sul State, Brazil. Arq. Bras. Med. Vet. Zootec., 68(5):
1187-1194.

20. Stephanie, N., Lim, S., Daub, A., Saini, S.S. and Azad, K.K. (2010) Benign monoclonal gammopathy in a dog exhibiting a low antibody titer to Ehrlichia canis. J. Clin. Immunol. Immunopathol. Res., 2(1): 9-14.

21. Camus, M.S., Krimer, P.M., Leroy, B.E. and Almy, F.S. (2010) Evaluation of the positive predictive value of serum protein electrophoresis beta-gamma bridging for hepatic disease in three domestic animal species. Vet. Pathol., 47(6): 1064-1070.

22. Cerón, J.J., Eckersall, P.D. and Martínez-Subiela, S. (2005) Acute phase proteins in dogs and cats: Current knowledge and future perspectives. Vet. Clin. Pathol., 34(2): 85-99.

23. Rikihisa, Y., Yamamoto, S., Kwak, I., Iqbal, Z., Kociba, G., Mott, J. and Chichanasiriwithaya, W. (1994) C-reactive protein and alpha 1-acid glycoprotein levels in dogs infected with Ehrlichia canis. J. Clin. Microbiol., 32(4): 912-917.

24. Köster, L.S., Lobetti, R.G. and Kelly, P. (2015). Canine babesiosis: A perspective on clinical complications, biomarkers, and treatment. Vet. Med. Res. Rep., 10(6): 119-128.

25. Manev, I. and Marincheva, V. (2018) Canine immune-mediated hemolytic anemia-brief review. Tradit. Mod. Vet. Med., 3(4): 59-64.

26. Mitchell, K.D., Kruth, S.A., Wood, R.D. and Jefferson, B. (2009) Serum acute phase protein concentrations in dogs with autoimmune hemolytic anemia. J. Vet. Intern. Med., 23(3): 585-591.

27. Griebsch, C., Arndt, G., Raila, J., Schweigert, F.J. and Kohn, B. (2009) C-reactive protein concentration in dogs with primary immune-mediated hemolytic anemia. Vet. Clin. Pathol., 38(4): 421-425.

\section{$* * * * * * * *$}

